УДК 552.32/.22/.23 (470.324)

DOI: https://doi.org/10.17308/geology.2020.2/2859

ISSN 1609-0691

Поступила в редакцию: 27.02.2020

Принята к публикации: 01.06.2020

Опубликована онлайн: 30.06 .2020

\title{
Никеленосный еланский комплекс Воронежского кристаллического массива: состав и номенклатура пород
}

\author{
(C2020 Р. А. Терентьев ${ }^{凶}$ \\ Воронеэсский государственный университет, \\ Университетская пл., 1, 394018, Воронеже, Российская Федерация
}

\begin{abstract}
Аннотация
Введение: В структуре докембрийского фундамента Воронежского кристаллического массива установлены субвулканические тела, отнесенные к еланскому норит-диоритовому комплексу. С ним связаны крупные месторождения сульфидного никеля Еланское и Елкинское. Несоотвествие традиционных названий горных пород комплекса существующим классификациям побудило написать данную работу.

Методика: Проведенные детальные петрохимические и петрографические исследования.

Результаты и обсуждение: Еланский и Елкинский петротипические плутоны подразделены на кумулятивную, дифференцированную и дайковую серии. Породы относятся к средним и кислым образованиям известково-щелочной серии; за исключением кумулатов, которые попадают на граничную область между средними и основными отрядами. Дифференцированная серия является наиболее распространенной и состоит из ультрамагнезиальных гранитоидов. Она образует непрерывные ряды: (1) биотит-ортопироксеновых меладиоритов - кварцевых меладиоритов - кварцевых меламонцодиоритов - мелагранодиоритов и (2) роговообманково-биотитовых и биотитовых, кварцевых диоритов - тоналитов - гранодиоритов - монцогранитов. Кумулаты представлены меланоритами, плагиоортопироксенитами, кварцсодержащими меланоритами и кварцевыми мелагаббродиоритами, а также горнблендитами, роговообманковыми мелагаббро и кварцевыми мелагаббродиоритами.

Заключение: Сделан вывод о необходимости пересмотра состава комплекса (предлагаемое новое название: меланорит-кварцмеладиорит-гранодиоритовый еланский комплекс). Выделенные разновидности предлагается использовать при геолого-разведочных работах для выявления петрографического контроля сульфидного оруденения.

Ключевые слова: палеопротерозой, сульфидные руды, рудоносные породы, классификация пород, ультрамагнезиальные гранитоиды.

Для циитирования: Терентьев Р. А. Никеленосный еланский комплекс Воронежского кристаллического массива: состав и номенклатура пород // Вестник Воронежского государственного университета. Серия: Геология. 2020. №2. С. 58-68. DOI: https://doi.org/10.17308/geology.2020.2/2859
\end{abstract}

\section{Введение}

В структуре докембрийского фундамента Воронежского кристаллического массива (ВКМ) по результатам бурения при поисковых работах на сульфидные никелевые руды установлены субвулканические тела, отнесенные к еланскому норит-диоритовому комплексу. С ним связаны крупные месторождения сульфидного никеля Еланское и Елкинское, приуроченные к одноименным крутопадающим штокообразным интрузивам. Еланское месторождение было открыто в

Контент доступен под лицензией Creative Commons Attribution 4.0 License.

\footnotetext{
函 Терентьев Роман Анатольевич, е-mail: terentiev@geol.vsu.ru
} 
1975 г. В. М. Богдановым с соавторами, во время производства глубинного геологического картирования докембрийского фундамента ВКМ масштаба 1: 500 000. Исследования вмещающих пород и руд проводились в разные годы и различными научными группами по керну скважин [1-13].

Традиционно считается, что тела еланского комплекса (размером 0.5-10 км²) чаще всего сложены в центральной части диоритами, в краевой - норитами мелко-среднезернистыми, порфировидными $[1,2,5$, 10, 12 и др.]. Уже на первых этапах исследования отмечался ряд специфических для норитов черт: высокая магнезиальность ( $\mathrm{MgO} 8.4-17.4$ мас.\%) при одновременно высоком содержании $\mathrm{SiO}_{2}$ (52.9-61 мас.\%), характерном для средних пород [6, 7, 10 и др.]. Те же авторы при описании «норитов» первой фазы еланского комплекса указывали на присутствие в них биотита (5$15 \%$ ), кварца и калишпата (в сумме до 10\%) и среднего плагиоклаза $\left(\mathrm{An}_{20-60}\right)$, а в «диоритах» второй фазы кварца (5-20\%) и калишпата (3-15\%). Выделялись мела-, мезо- и лейкократовые разновидности «норитов» $[4,10]$. Специфический состав «норитов» объяснялся контаминацией родоначального расплава коматиитовыми породами [3], коматиитовым составом расплава контаминированным фельзической континентальной корой $[6,12]$ или бонинитоподобным родоначальным составом $[8,13]$. Однако какой бы моделью мы не стремились объяснить происхождение той или иной породы, при ее описании необходимо руководствоваться составом, наблюдаемым в естественных или искуственных обнажениях, а не составом расплава в магматическом источнике.

Несоотвествие традиционных названий горных пород еланского комплекса существующим международным и российским петрохимическим и модальным классификациям, позволило пересмотреть их номенклатуру и видовые названия, чему, и посвящена данная работа.

\section{Геологическая позиция}

Расслоенные мафит-ультрамафитовые интрузии и мафит-гранитоидные субвулканические тела широко распространены в Воронцовском террейне, который геотектонически рассматривается как часть палеопротерозойского Восточно-Сарматского орогена между архейскими сегментами Восточно-Европейского кратона. Мафит-гранитоидные массивы еланского комплекса локализованы восточнее крупного Елань-Коленовского ультрамафит-мафит-диоритового расслоенного плутона [1] с возрастом по U-Pb данным по цирконам $2073 \pm 8.3$ млн лет [13]. Все плутоны еланского комплекса внедрены в палеопротерозойские терригенные преимущественно метапелитовые породы воронцовской серии. Геохимические по валовым пробам [5, $8,13]$, минералого-петрографические [4, 5, 8, 10 и др.] и геохронологические по цирконам [13] исследования пород Еланского и Елкинского плутонов, традиционно разделяемых на две фазы, и сопутствующих им даек порфиритов демонстрируют, что они одновозрастны и комагматичны.

На уровне эрозионного среза, погребенного под чехлом фанерозойских осадков мощностью 150-200 м, плутоны еланского комплекса представляют концентрически зональные тела около 3-4 км в диаметре с зонами дифференцированными от краевых мафитов до гранитоидов в центре. Пироксеновые роговики, развитые в краевых зонах метаосадочных ксенолитов и вдоль контакта интрузий, а также порфировидные структуры пород и присутствие низкоглиноземистой роговой обманки показывают кристаллизацию в малоглубинных условиях, вероятно, менее 1 кбар. Помимо этого большинством исследователей отмечаются секущие биотит-амфиболовые гранитоиды, которые содержат меланократовые породы в качестве ксенолитов, что позволяло рассматривать их как породы второй фазы.

Еланский и Елкинский плутоны подразделены на кумулятивную, дифференцированную и дайковую серии [14]. Кумулятивная серия преобладает в краевой части плутонов, а также среди разреза дифференцированной серии, нарушая общий тренд от мафитов к гранитоидам, и состоит из массивных меланократовых мелко-среднезернистых и среднезернистых пород, которые часто несут промышленное сульфидное никелевое оруденение. Кумулаты являются наиболее примитивными породами и характеризуются минимальными концентрациями несовместимых компонентов. Дифференцированная серия залегает в центре массивов и имеет мощность более 1.5 км. Она состоит из чередующихся высокомагнезиальных биотит-ортопироксеновых и амфибол-биотит-ортопироксеновых диоритов-гранитоидов, которые ближе к ядру массива могут постепенно переходить или иметь резкие контакты с биотитовыми и биотит-роговообманковыми гранитоидами. Породы плутонов еланского комплекса, и реже метаосадки вблизи интрузий, секутся дайками синплутонических порфиритов (рис. 1).

\section{Фактический материал и методы исследования}

Образцы представляют собой керн скважин, вкрывших Еланский и Елкинский петротипические массивы еланского комплекса. Осуществлено петрографическое исследование 188 шлифов и приближенно-количественная оценка модальных содержаний главных породообразующих минералов - более 500 шлифов. Использованы петрохимические данные А. В. Переславцева, из его диссертации [5] и наши опубликованные результаты $[8,13]$.

Кристаллооптические исследования осуществлены на прямом оптическом поляризационном микроскопе OLYMPUS BX51-P. Количественно-минеральный подсчет в шлифах осуществлен линейным методом с вычислением длин минеральных индивидов (Аналитик: Р. А. Терентьев). Объектив $25^{\mathrm{x}}$ или $10^{\mathrm{x}}$, расстояние между линиями 0.5-1.0 мм, количество линий от 10 до 20. 

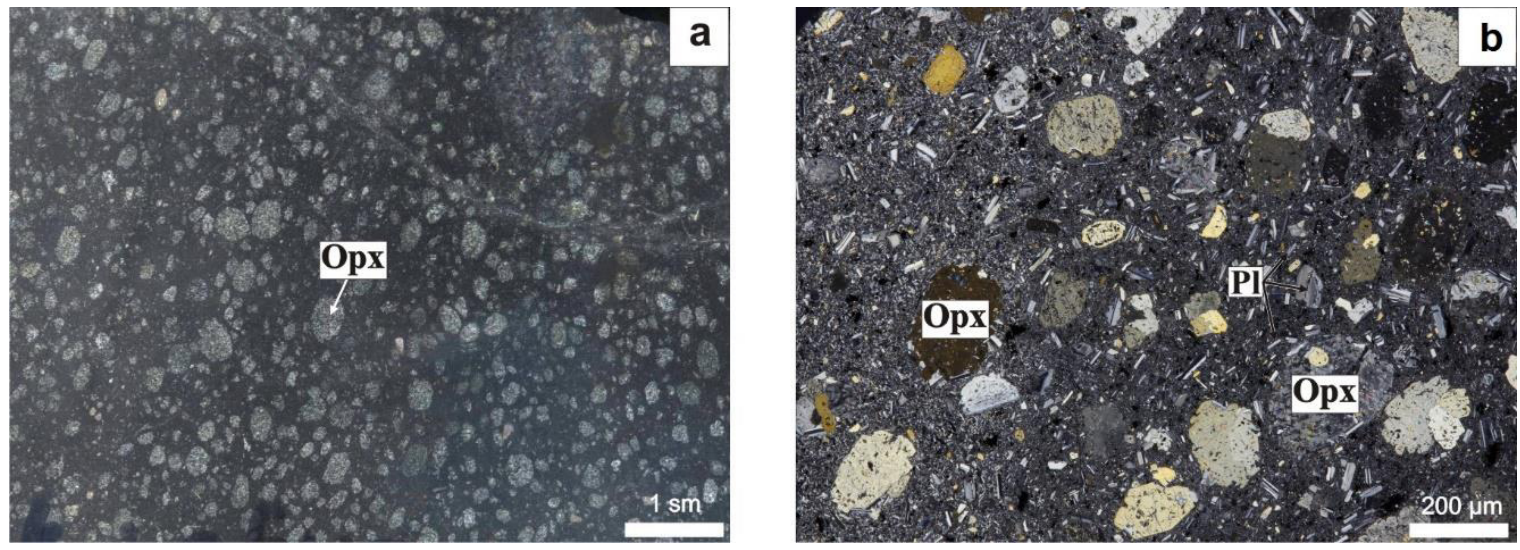

Рис. 1. Фотографии порфирита еланского комплекса: $a$-керн, $b$ - шлиф в скрещенных николях.

[Fig. 1. Photos of the Elan complex porphyrite: $a$ - core, $b$ - thin section in crossed nicols.]

Фотографии пород и шлифов выполнены на фотоаппарате CANON EOS 650B, объектив CANON EF 100 $\mathrm{mm} \mathrm{f/2.8L} \mathrm{Macro} \mathrm{IS} \mathrm{USM.} \mathrm{Фотографии} \mathrm{шлифов} \mathrm{сняты}$ с применением поляризационного фильтра MARUMI wide MC-PL. Фотограф Ю. Н. Шнырев.

Образцы пород для силикатного анализа были истерты в порошок с крупностью зерен 50 мкм. Затем методом квартования отобрана навеска массой 1 г. Далее образцы были высушены при температуре $110^{\circ} \mathrm{C}$ до состояния воздушно-сухой пробы, затем - прокалены до постоянной массы при температуре $1000^{\circ} \mathrm{C}$. Подготовка излучателей для анализа породообразующих элементов выполнена путем плавления 0.5 г порошка пробы, 2 г тетрабората лития и 2 г метабората лития в муфельной печи с последующим отливом стеклообразного диска. Химический состав проб определен на рентгенофлуоресцентном спектрометре S8 Tiger (Bruker AXS GmbH, Германия). Результаты исследований получены на оборудовании ЦКПНО ВГУ. При калибровке спектрометра и для контроля качества измерений были использованы государственные стандартные образцы химического состава горных пород - СГ4 (ГСО №10135-2012), СГ-3 (ГСО № 3333-85), СТ СЭВ 2300-80, СКД-1 (ГСО №6103-91). Точность анализа составляла $1-2 \%$ отн. \% для элементов с концентрациями выше 1-5 мас. \% и до 5 отн. \% для элементов с концентрацией ниже 0.5 мас. \%.

Локальные анализы минералов выполнены на электронном микроскопе Jeol 6380LW с системой количественного энергодисперсионного анализа «Inca» (ВГУ). Условия анализа: ускоряющее напряжение 20 кв, ток зонда $1.2 \mathrm{~mA}$, время набора спектра 90 сек, диаметр пучка 1-3 мкм. ZAF коррекция при расчете содержания окислов и оценка точности проводились с помощью комплекта программ математического обеспечения системы. Точность анализа систематически контролировалась по эталонным образцам природных и синтетических минералов.

\section{Понятийная база}

Главной сложностью при изучении изверженных образований еланского комплекса оказался выбор кор невого названия для пород первой фазы: норит или диорит, и пород второй фазы: диорит или гранодиорит? В таблице 1 приведены определения терминов норит и диорит из наиболее авторитетных научных и производственных изданий геологической отрасли. Резюмировав определения (табл. 1) очевидно, что диорит это средняя порода ( $\mathrm{SiO}_{2}$ от 53 до 64 мас.\%), а норит основная $\left(\mathrm{SiO}_{2}\right.$ от 46 до 53 мас.\%). Петрографический кодекс России [15] четко регламентирует (стр. 26): «... для полнокристаллических пород, в которых отчетливо распознаются составляющие их минераль, в дополнение к TAS-диаграмме (или в случае, когда химические анализы не производились) для классификации пород на уровне семейств могут применяться минералогические классификационные диаграммы. ...Для всех силикатных пород, кроме ультрамафических, применяется диаграмма QAPF (квари - щелочной полевой шпат - плагиоклаз - фельдшпатоид), по A. Streckeisen $(1976,1978) »$. Подкомиссия по систематике изверженных пород Международного союза геологических наук [16] указывает, что на диаграмме QAPF корневые названия диорит и габбро различаются по составу плагиоклаза и цветному индексу: «...если Ап меньше 50, то порода - диорит, если Ап больше 50, порода - габбро...». Этими принципами будем руководствоваться при определении номенклатуры пород еланского комплекса.

\section{Петрография}

Kумулаты - наиболее меланократовые темно-серые, зеленовато-темно-серые до черных породы (рис. 2). Структуры пород мелко-среднезернистые до среднезернистых, кумулятивные (идиоморфные изометричные кристаллы пироксенов, оливина, иногда плагиоклаза и роговой обманки погружены в интеркумулусную основную массу, состоящую из кварца, калишпата, биотита, иногда роговой обманки, рис. 3) и гипидиоморфные.

Часто в кумулятивных породах встречаются неправильной или изометричной формы крупные кристаллы оливина порядка 1мм. Содержание оливина не редко превышает 5\%. Ортопироксен - наиболее распространенный идиоморфный минерал кумулатов. Содержание 
Табл. 1. Определения терминов норит и диорит

[Table 1. Definitions of terms norite and diorite]

\begin{tabular}{|l|l|c|}
\hline \multicolumn{1}{|c|}{$\begin{array}{c}\text { Норит } \\
\text { [Norite] }\end{array}$} & \multicolumn{1}{|c|}{$\begin{array}{c}\text { Ссылкарит } \\
\text { [Diorite] }\end{array}$} \\
[Reference]
\end{tabular}

ортопироксена варьирует от 20 до 57\% достигая $80 \%$ в плагиоортопироксенитах.

Роговая обманка в кумулатах идиоморфная, часто с визуальной зональностью (бурые ядра и зеленые каймы) составляет от 40 до 90\%. Чаще всего роговая обманка представлена идиоморфными кристаллами наряду с ортопироксеном и пойкилитовыми зернами плагиоклаза. В ортопироксеновой серии кумулятивных пород - это каймы вокруг орто- или клинопироксена, самостоятельные субидиоморфные и ксеноморфные зерна.

Второстепенные минералы кумулатов представлены субидиоморфными клинопироксеном и биотитом, ксеноморфными кварцем, калиевым полевым шпатом.

Ортопироксен-биотитовые дифференцииты соответствуют в традиционном понимании первой фазе еланского комплекса (рис. 2, 3) и характеризуются широким набором породообразующих минералов: оливин, ортопироксен, клинопироксен, биотит, роговая обманка, плагиоклаз, кварц и калиевый полевой шпат. Структуры пород порфировидные (вкрапленники - ортопироксен, редко плагиоклаз), гипидиоморфные (ряд идиоморфизма: оливин - ортопироксен - клинопироксен - плагиоклаз, биотит, роговая обманка - кварц и калиевый полевой шпат); структуры основной массы мелкозернистые в равномернозернистых (гипидиоморфных) разновидностях и тонкозернистые в порфировидных разновидностях пород.
Оливин встречается спорадически, как правило, в наиболее меланократовых разновидностях. Он представлен, чаще всего, включениями в фенокристаллах ортопироксена, где замещается агрегатами иддингсита-боулингита. Редко встречаются неправильной или изометричной формы крупные кристаллы. Оливин, контактирующий с лейкократовой составляющей пород, всегда изменен, а неизмененные кристаллы всегда окружены реакционной каймой ортопироксена и в единичных случаях биотита и роговой обманки. Содержание оливина не превышает $3 \%$.

Ортопироксен широко варьирует от 9 до 50\%. Он, в большинстве образцов, слагает фенокристаллы размером 0.3-2.0 редко более мм. Вкрапленники ортопироксена часто содержат включения оливина, клинопироксена, врастания ойкокристаллов плагиоклаза и биотита. Судя по степени идиоморфизма, ортопироксен кристаллизуется или совместно с оливином, или сразу после него.

Клинопироксен представлен в большинстве образцов в небольшом количестве, среднее содержание $1 \%$, в единичных случаях достигает 5\%. Формирует мелкие самостоятельные кристаллы с каймой роговой обманки или обрастает ортопироксен.

Роговая обманка также является неотъемлемой частью ортопироксен-биотитовых дифференциатов. Ее количество варьирует от 0 до $17 \%$. Она формирует каймы вокруг орто- или клинопироксена, самостоятельные субидиоморфные и ксеноморфные зерна. 

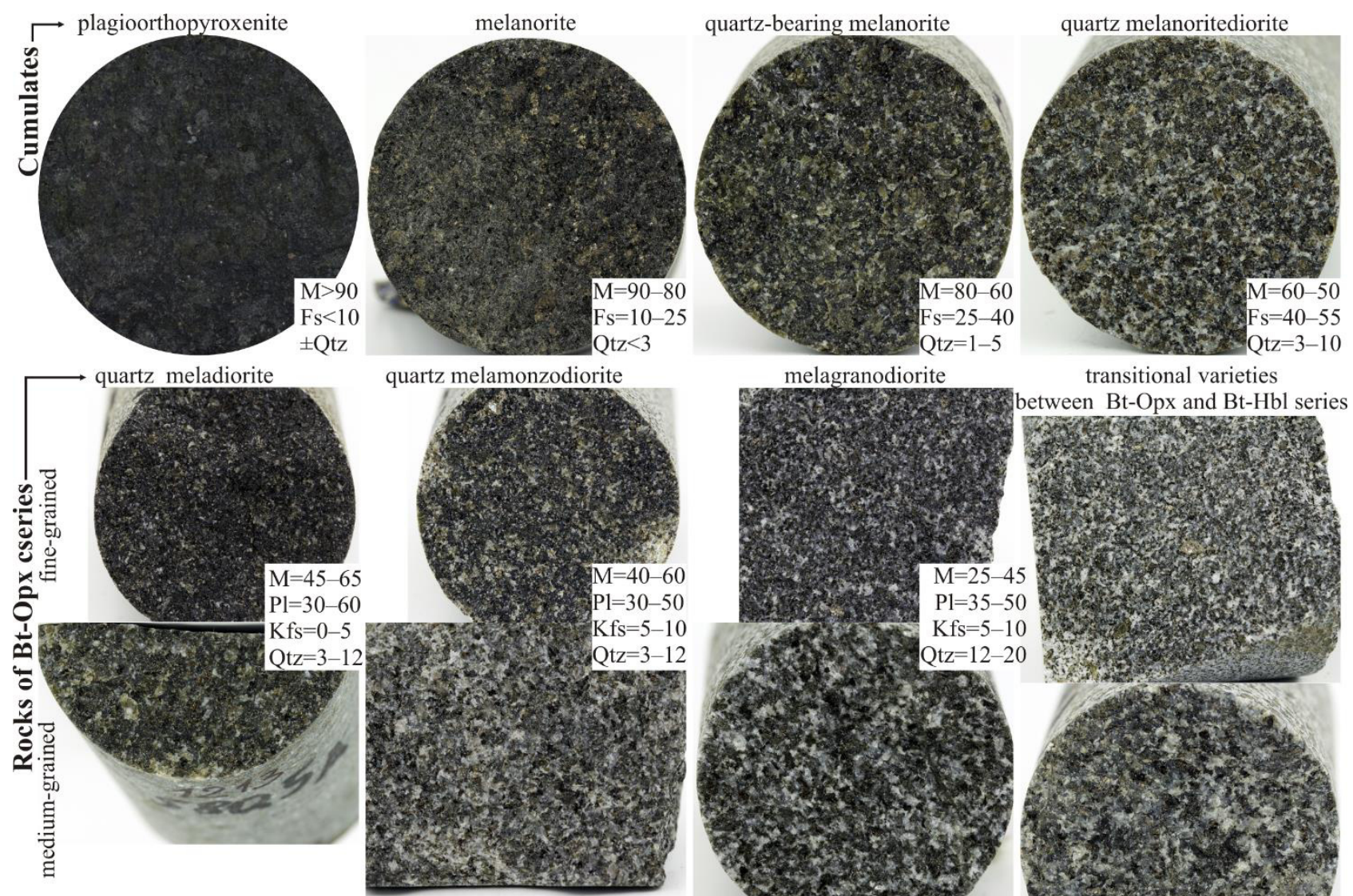

quartz melamonzodiorite
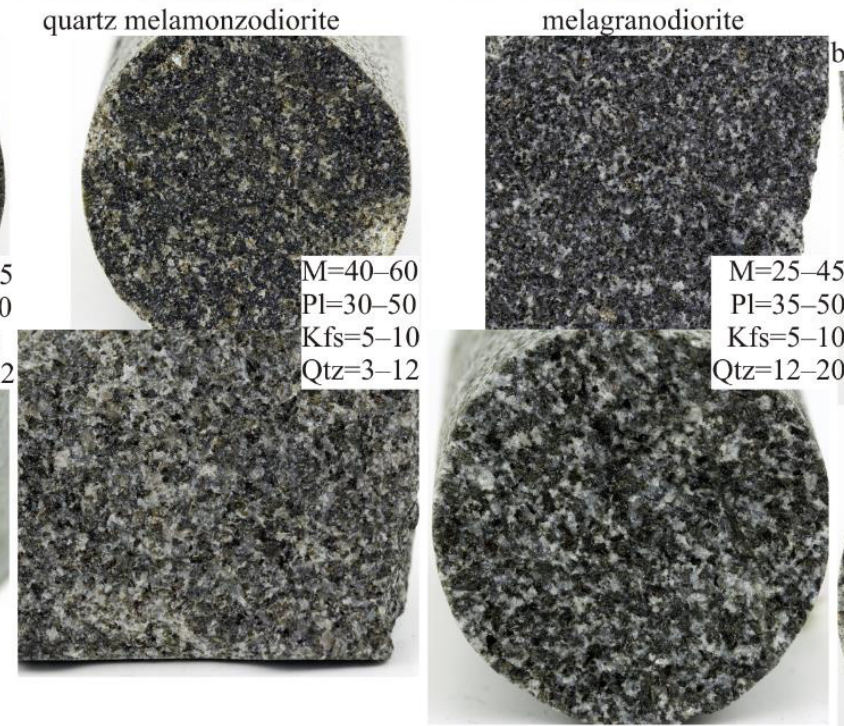

transitional varieties

between Bt-Opx and Bt-Hbl series

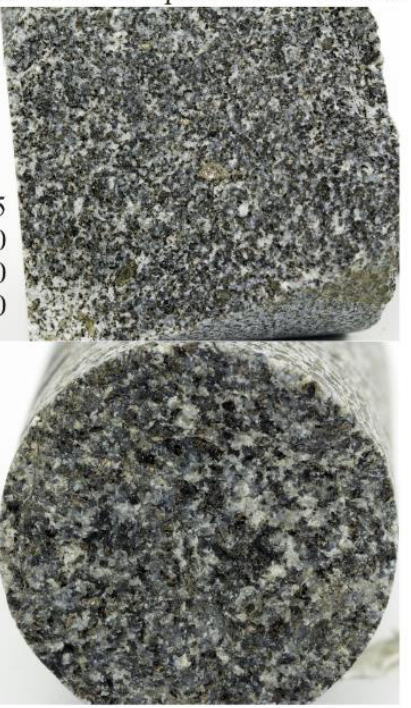



tonalite
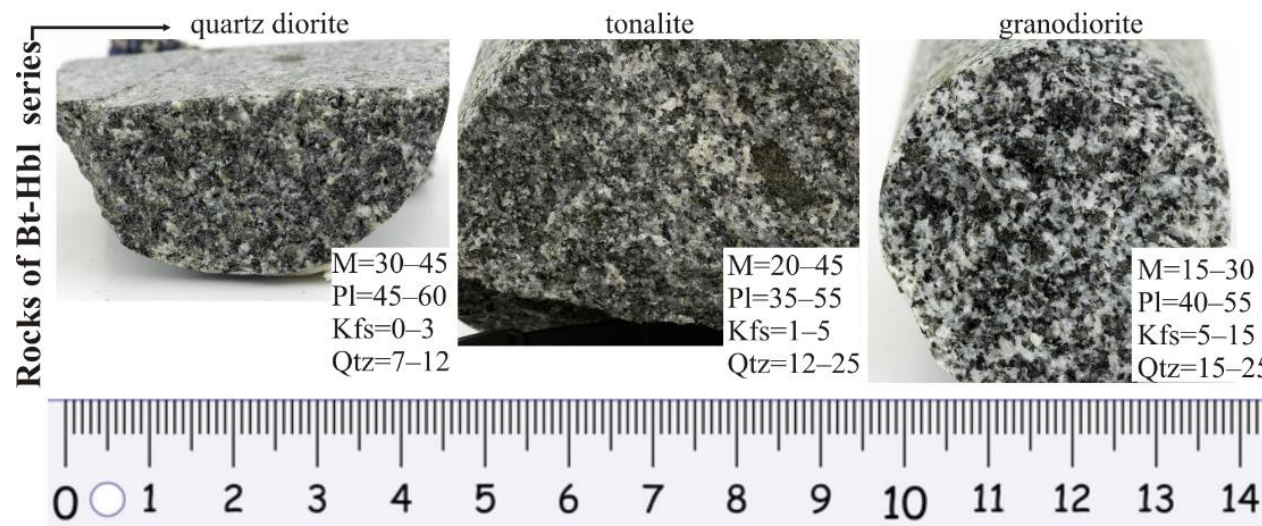

monzogranite
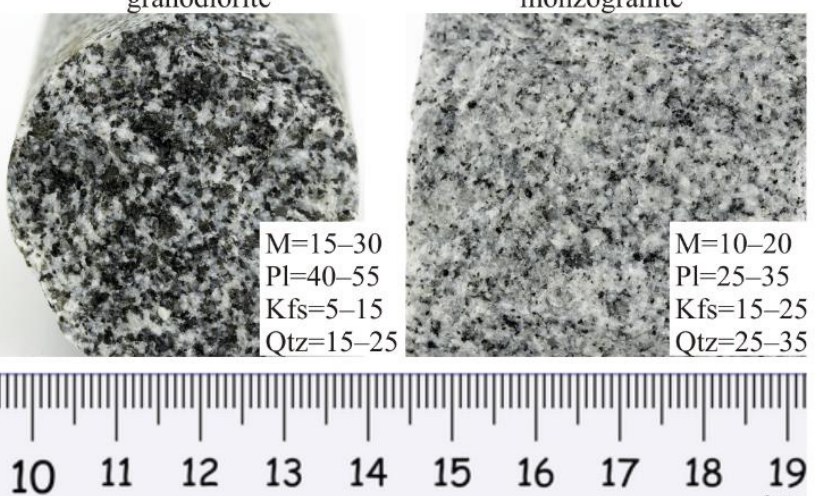

1415

1516

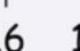

Рис. 2. Фотографии типовых образцов породных серий еланского комплекса (свежий скол, керн скважин). Сокращения: $M-$ сумма темноцветных минералов (цветной индекс), Fs - сумма полевых шпатов ( $P l$ - плагиоклаз $+K f s$ - калиевый полевой шпат), Qtz - кварц, $O p x$ - ортопироксен, $B t$ - биотит, $H b l$ - магматический амфибол. Фото выполнил Ю. Н. Шнырев.

[Fig. 2. Photographs of typical samples of the Elan complex rock series (fresh spalling, drillhole cores). Abbreviations: $M$ - mafic and related minerals (color index), $F s$ - feldspars ( $P l$ - plagioclase $+K f s-\mathrm{K}$-feldspar), $Q t z$ - quartz, $O p x$ - orthopyroxene, $B t-$ biotite, $H b l-$ magmatic amphibole. Photo taken by Yu. N. Shnyrev.]

Биотит характеризуется ксеноморфизмом. Он кристаллизуется после плагиоклаза. Количества его изменяются от 3\% в наиболее меланократовых породах до 25\% в самых лейкократовых и мезократовых образцах главной совокупности пород.

Плагиоклаз представлен лейстами в порфировидных тонкозернистых разновидностях и таблитчатыми кристаллами в гипидиоморфных мелкозернистых раз- новидностях. Редко образует фенокристаллические вкрапления с отчетливой осциляционной зональностью. Усредненный состав лейстовидного и таблитчатого плагиоклаза главной совокупности пород соответствует андезину $\mathrm{An}_{35-42}$ (рис. 4). Фенокристаллы плагиоклаза биотит-ортопироксеновых дифференциатов и плагиоклаз кумулятивных пород характеризуется близким составом от андезина до лабрадора $\mathrm{An}_{40-70}$ 

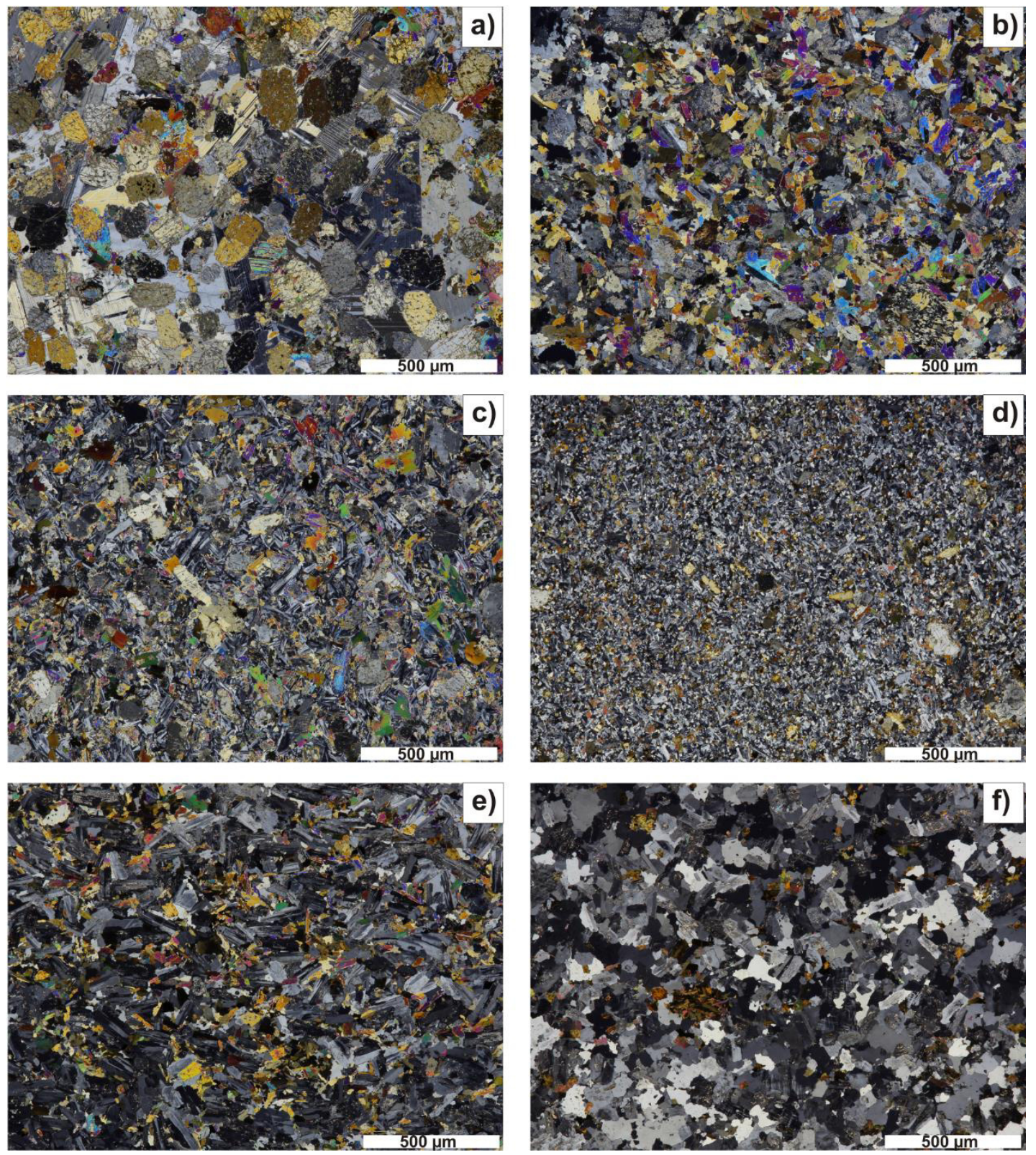

Рис. 3. Микрофотографии типовых образцов породных серий еланского комплекса. Кумулаты: $a$ ) плагиоклаз-ортопироксеновый (меланорит), $b$ ) плагиоклаз-роговообманковый (роговообманковое мелагаббро); биотит-ортопироксеновая серия: $c$ ) кварцевый меладиорит, $d$ ) мелагранодиорит; амфибол-биотитовая серия: $e$ ) кварцевый диорит, $f$ ) монцогранит. Фото выполнил Ю. Н. Шнырев (http://ostrov-mineralov.ru/).

[Fig. 3. Microphotographs of typical samples of the Elan complex rock series. Cumulates: a) plagioclase-orthopyroxene (melanorite), $b$ ) plagioclase-hornblende (hornblende melagabbro); biotite-orthopyroxene series: c) quartz meladiorite, $d$ ) melagranodiorite; amphibole-biotite series: $e$ ) quartz diorite, $f$ ) monzogranite. Photo taken by Yu. N. Shnyrev (http://ostrov-mineralov.ru/).]

(рис. 4). Усредненные составы плагиоклаза, вычисленные экспресс-методом Мишель-Леви совпадают со статистическими данными локальных микрозондовых анализов.

Кварц и калиевый полевой шпат всегда занимают интерстиции либо в виде тонкозернистой массы, либо в виде крупных одновременно погасающих ойкокристаллов. Количество кварца изменяется от 0.4 до $19 \%$, калиевого полевого шпата от 0 до $13 \%$.

Амфибол-биотитовые дифференциаты соответствуют в традиционном понимании второй фазе еланс- кого комплекса (рис. 2, 3) и характеризуются узким набором породообразующих минералов: биотит, роговая обманка, плагиоклаз, кварц и калиевый полевой шпат. Структуры пород гипидиоморфные (ряд идиоморфизма: плагиоклаз - роговая обманка - биотит кварц и калиевый полевой шпат), редко порфировидные (вкрапленники - роговая обманка, предположительно пседоморфозы по пироксену и плагиоклаз); структуры основной массы - мелкозернистые и мелко-среднезернистые. 


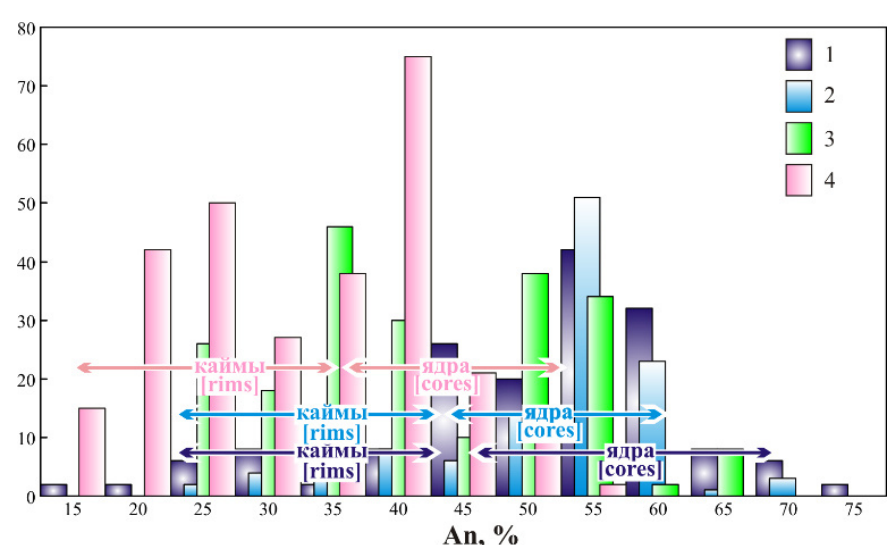

Рис. 4. Гистограммы содержаний анортитового минала в плагиоклазе кумулятивной и дифференцированной серий еланского комплекса: 1 - кумулаты, 2 - Bt-Opx серия (фенокристаллы), 3 - BtОрх серия (лейсты), 4 - Bt-Hbl серия.

[Fig. 4. Histograms of the anorthite contents in the plagioclase of the Elan complex cumulates and differentiated rock series: 1 - cumulates, 2 - Bt-Opx series (phenocrystals), 3 - Bt-Opx series (laths), 4 - Bt-Hbl series.]

Плагиоклаз чаще всего представлен идиоморфными таблитчатыми кристаллами, реже изометричными зернами с отчетливой осциляционной зональностью (в центре - андезин, по краям - олигоклаз). Состав плагиоклаза варьирует от андезина до олигоклаза, модальные значения - $\mathrm{An}_{20-40}$ (рис. 4). Вычисления экспресс-методом Мишель-Леви также соотвествуют составам олигоклаз-андезин. Модальное содержание плагиоклаза около 47\% (35-60\%).

Роговая обманка распространена менее остальных породообразующих минералов гранитоидов амфибол-биотитовой серии. Ее количество варьирует от 0 до $30 \%$. В большинстве образцов - это псевдоморфозы, предположительно, по фенокристаллам пироксена, самостоятельные субидиоморфные зерна, сростки зерен или сростки с биотитом.

Биотит характеризуется субидиоморфными формами. Он кристаллизуется после плагиоклаза и роговой обманки. Количества его изменяются от $6 \%$ до $25 \%$.

Кварц и калишпат ксеноморфны относительно остальных породообразующих минералов. Кварц в виде отдельных зерен, а калишпат, как правило, в виде единых пойкилокристаллов с одинаковым погасанием. Встречаются как сростки кварца с плагиоклазом (мирмекиты), так и прорастания калишпата в плагиоклазе (антипертиты). Количество кварца изменяется от $10 \%$ до 26\%, калиевого полевого шпата от 1 до $25 \%$.

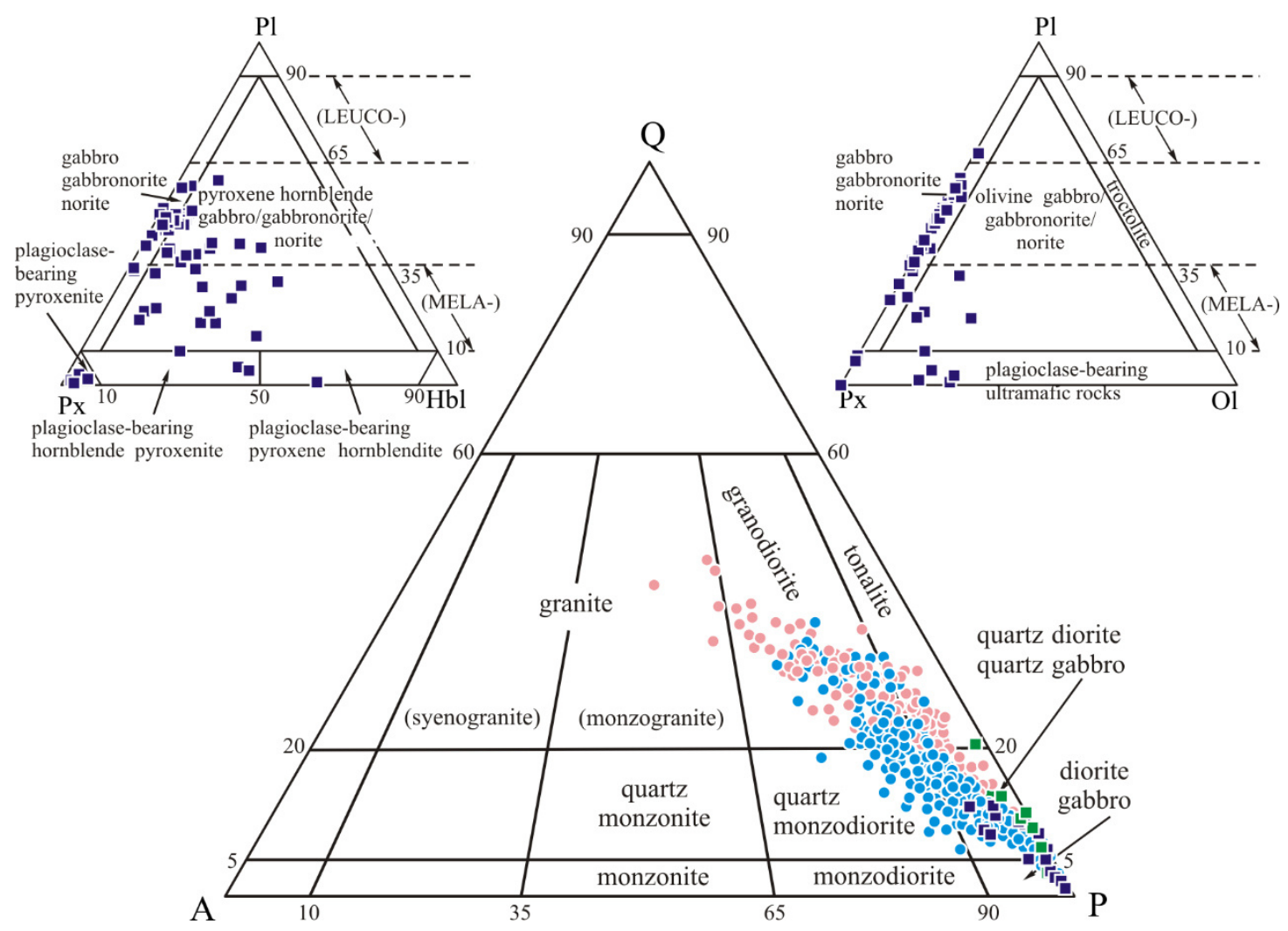

Рис. 5. Модальный минеральный состав кумулатов (квадраты), пород дифференцированных серий (кружки) биотит-ортопироксеновой (голубые) и биотит-амфиболовой (розовые) еланского комплекса на классификационных диаграммах QAP, $\mathrm{Pl}$ $\mathrm{Px}-\mathrm{Ol}$ и $\mathrm{Pl}-\mathrm{Px}-\mathrm{Hbl}[16,19]$. $Q$ - кварц, $A$ - щелочные полевые шпаты, $P$ и $P l$ - плагиоклаз, $P x$ - пироксены, $\mathrm{Ol}-$ оливин, $\mathrm{Hbl}-$ роговая обманка.

[Fig. 5. Modal mineral composition of cumulates (squares), biotite-orthopyroxene (blue) and biotite-amphibole (pink) differentiated rock series (circles) of the Elan complex on the QAP, Pl-Px-Ol and Pl-Px-Hbl classification diagrams [16, 19]. $Q$ - quartz, $A$ - alkaline feldspars, $P$ and $P l$ - plagioclase, $P x$ - pyroxenes, $O l$ - olivine, $H b l$ - hornblende.] 


\section{Петрохимия}

По петрохимическому составу (рис. 6) кумулаты и породы дифференцированной серии еланского комплекса (подразумеваются все биотит-ортопироксеновые разновидности, выделяемые предшественниками в качестве первой фазы) являются средними и даже кислыми $\left(\mathrm{SiO}_{2}=52.71-65.3\right.$ мас.\%, два образца со значением менее 52 мас.\%) и относятся к семействам известково-щелочных, от умеренно- до высокоглиноземистых $\mathrm{Al}_{2} \mathrm{O}_{3} /\left(\mathrm{Fe}_{2} \mathrm{O}_{3}+\mathrm{FeO}+\mathrm{MgO}\right)=0.38-1.57$, низко-, умереннощелочных $\left(\mathrm{Na}_{2} \mathrm{O}+\mathrm{K}_{2} \mathrm{O}<8\right.$ мас. \%) диоритов, кварцевых диоритов, и гранодиоритов с низким и сред- ним $(<0.25-1.65) \mathrm{K}_{2} \mathrm{O} / \mathrm{Na}_{2} \mathrm{O}$ отношением.

Самые лейкократовые породы дифференцированной серии еланского комплекса (подразумеваются все биотит-роговообманковые разновидности, выделяемые ранее в качестве второй фазы) являются кислыми и в меньшей степени средними $\left(\mathrm{SiO}_{2}=60.58-69.75\right.$ мас. $\%$ ) и относятся к семействам известково-щелочных, от умеренно- до высокоглиноземистых $\mathrm{Al}_{2} \mathrm{O}_{3} /\left(\mathrm{Fe}_{2} \mathrm{O}_{3}+\mathrm{FeO}+\mathrm{MgO}\right)=0.70-2.89$, низко-, умереннощелочных $\left(\mathrm{Na}_{2} \mathrm{O}+\mathrm{K}_{2} \mathrm{O}<8\right.$ мас. \%) кварцевых диоритов, тоналитов и гранодиоритов с низким и средним $(<0.5-1.63) \mathrm{K}_{2} \mathrm{O} / \mathrm{Na}_{2} \mathrm{O}$ отношением.

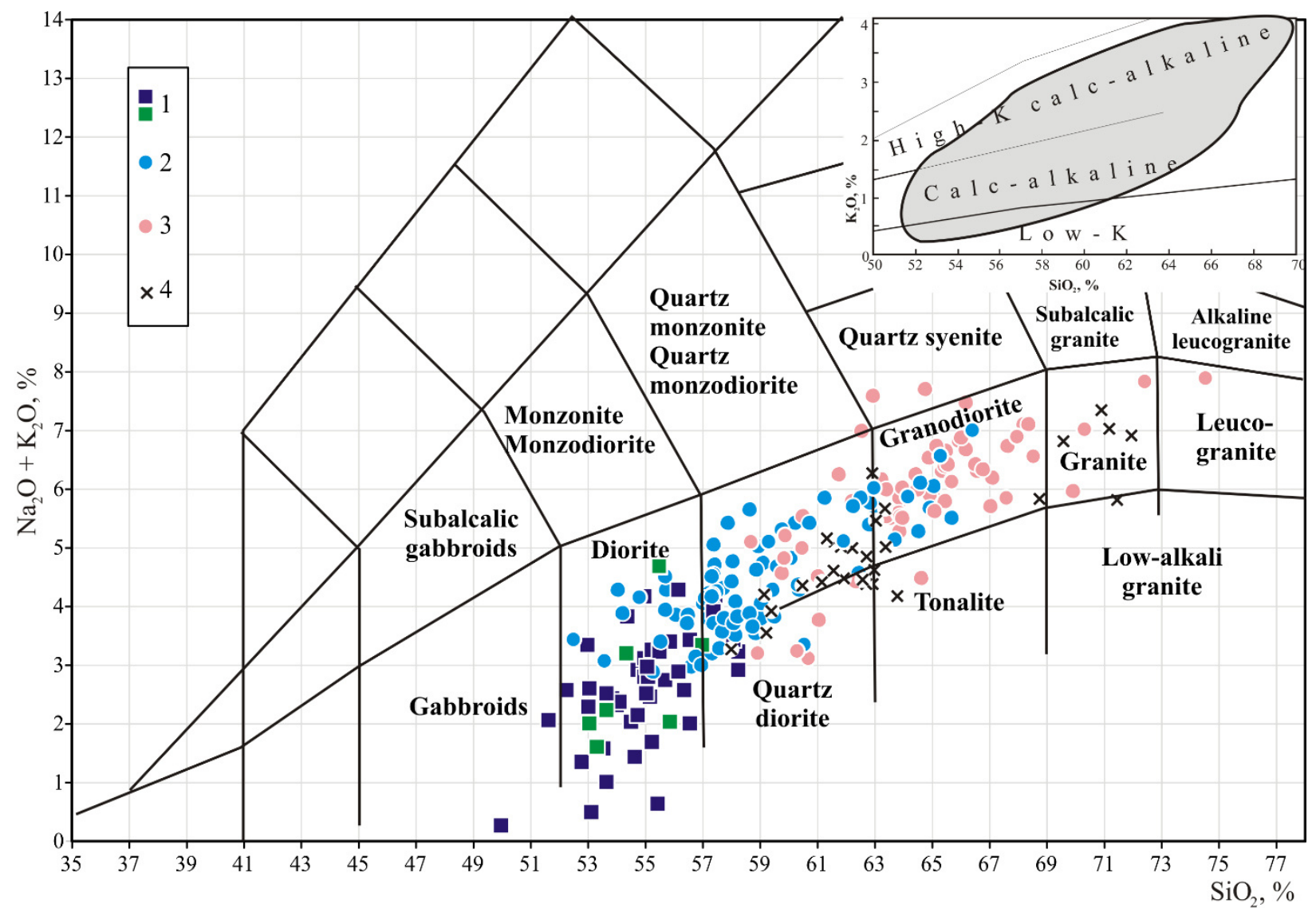

Рис. 6. TAS-диаграмма для пород еланского комплекса ВКМ: 1 - кумулятивная серия, 2 - дифференцированная серия (биотитортопироксеновая), 3 - дифференцированная серия (биотит-амфиболовая), 4 - дайковая серия (порода + основная масса).

[Fig. 6. TAS diagram for the Elan complex rocks of the VCM: 1 - cumulate series, 2 - differentiated series (biotite-orthopyroxene), 3 differentiated series (biotite-amphibole), 4 - dyke series (whole rock + groundmass).]

\section{Обсуждение результатов}

Цветной индекс пород ортопироксен-биотитовой серии еланского комплекса изменяется от 25 до $63 \%$. Значения 75\% превышается только в породах кумулятивной структуры и достигает $92.7 \%$ в плагиоортопироксените. Это свидетельствует о том, что породы, относимые ранее к первой фазе, состоят из среднего плагиоклаза, являются кварц-, калишпатсодержащими или кварцевыми и калишпатовыми, цветной индекс (оливин + пироксены + роговая обманка + биотит + рудные и акцессорные минералы) не превышает 63\%, что позволяет применять к ним классификационную диаграмму QAP $[16,19]$ (рис. 5). Кумулаты (около 10-
15\% образцов) - это меланократовые породы с минимальными содержаниями кварца, составом плагиоклаза приближающегося к лабрадору, что позволяет применять к ним классификационные диаграммы P1Px-Ol и Pl-Px-Hbl [16, 19] (рис. 5).

Результаты количественно-минеральных подсчетов свидетельствуют о том, что породы, относимые ранее к второй фазе, состоят из среднего и кислого плагиоклаза, являются кварцевыми и калишпатовыми, цветной индекс (роговая обманка + биотит + рудные и акцессорные минералы) не превышает 43\%, что позволяет применять к ним классификационную диаграмму QAP $[16,19]$ (рис. 5). Кумулаты амфибол-биотитовой 
серии (около 5\% образцов) - это меланократовые породы с минимальными содержаниями кварца, составом плагиоклаза приближающегося к андезину, большим количеством роговой обманки - составы переходных пород - габбродиоритов.

Модальные составы кумулатов, дифференцированных пород ортопироксен-биотитовой (или первая фаза) и амфибол-биотитовой (или вторая фаза) серий еланского комплекса вынесены на минералогические классификационные диаграммы (рис. 5). Соотношения кварца и полевых шпатов, темноцветных минералов и состав плагиоклаза свидетельствуют о том, что среди пород, относимых ранее к первой фазе, преобладают меладиориты и кварцевые меладиориты, которые закономерно дифференцируются через кварцевые меламонцодиориты до мелагранодиоритов. По составу темноцветных минералов вся серия пород относится к биотит-ортопироксеновым разновидностям. Кумулаты представлены флогопитовыми и флогопит-роговообманковыми меланоритами, плагиоортопироксенитами и их относительно лейкократовыми аналогами - флогопит-ортопироксеновыми кварцсодержащими меланоритами и кварцевыми мелагаббродиоритами (меланоритдиоритами, рис. 2). По цветному индексу, окраске пород в целом и размеру зерен ортопироксеновой серии соотвествуют флогопитовые и пироксеновые горнблендиты, роговообманковые мелагаббро и кварцевые мелагаббродиориты с широко развитой роговой обманкой как главного темноцветного минерала вместо ортопироксена.

Породы, относимые ранее ко второй фазе, группируются в единый тренд от кварцевых диоритов через тоналиты и гранодиориты до монцогранитов. По составу темноцветных минералов вся серия пород относится к роговообманково-биотитовым или биотитовым разновидностям.

По содержанию $\mathrm{K}_{2} \mathrm{O}$ большинство образцов еланского комплекса характеризуются нормальной и высокой калиевостью (см. врезку на рис. 6). Высокая магнезиальность, наряду со средним и кислым химизмом, позволяет рассматривать породы еланского комплекса как ультрамагнезиальные [20] кварц-полевошпатовые породы (гранитоиды в широком смысле слова - sensu lato).

Учитывая, что плутоны еланского комплекса несут промышленное сульфидное никелевое оруденение, необходимо выявление петрографического контроля магматического оруденения. Для выполнения этой задачи предлагается использовать при геолого-съемочных, поисковых и разведочных работах на сульфидный никель выделенные в данной работе разновидности пород (см. рис. 2), которые, обобщенно, реально диагностировать не только по результатам исследований под микроскопом, но и в полевых условиях при условии детального макроскопического описания керна скважин.

\section{Выводы}

На основании петрохимических и петрографических данных следует:
1. Породы еланского комплекса относятся к средним и кислым образованиям извествово-щелочной серии; за исключением кумулатов, которые попадают на граничную область между средними и основными отрядами.

2. Породы, относимые предшественниками к первой фазе, образуют непрерывный ряд биотит-ортопироксеновых, иногда роговообманковосодержащих меладиоритов - кварцевых меладиоритов - кварцевых меламонцодиоритов - мелагранодиоритов (жирным шрифтом выделены преобладающие разновидности).

3. Породы, относимые предшественниками ко второй фазе, образуют непрерывный ряд роговообманково-биотитовых и биотитовых, кварцевых диоритов тоналитов - гранодиоритов - монцогранитов (жирным шрифтом выделены преобладающие разновидности).

4. Рекомендуется пересмотреть формационную принадлежность еланского комплекса в региональных схемах корреляции и легендах к геологическим картам раннего докембрия ВКМ с учетом данных, изложенных в статье. Для демонстрации дифференцированности комплекса предлагается использовать следующее наименование меланорит-кварцмеладиорит-гранодиоритовый еланский комплекс.

Конфликт интересов: Автор декларирует отсутствие явных и потенциальных конфликтов интересов, связанных с публикацией настоящей статьи.

\section{ЛИТЕРАТУРА}

1. Бочаров В. Л., Фролов С. М., Чернышов Н. М. Строение и состав Еланьского никеленосного плутона в краевой части Воронежского кристаллического массива: Статья I Геология и петрография // Известия Вузов. Геология и разведка. 1986. № 4. C. 10-19.

2. Бочаров В. Л., Фролов С. М., Чернышов Н. М. Строение и состав Еланьского никеленосного плутона в краевой части Воронежского кристаллического массива: Статья II Петрохимия // Известия Вузов. Геология и разведка. 1986. № 5. С. $42-48$.

3. Бочаров В. Л., Плаксенко А. Н., Фролов С. М., Касатов А. С. О первично-коматиитовом источнике никелевых сульфидных руд в норит-диоритовых интрузиях Воронежского кристаллического массива // Геохимия. 1987. №3. С. 430-437.

4. Бочаров В. Л., Плаксенко А. Н. Петрологические критерии выделения норит-диоритовых интрузий с регенерированными никелевыми сульфидными рудами // Советская геология. 1989. № 5. С. 38-43.

5. Переславцев А. В. Петрология норит-диоритовых интрузий докембрия Воронежского кристаллического массива в связи с проблемой их никелевого потенциала: дис. ... канд. геол.-мин. наук. Воронеж: ВГУ, 1993. - 197 с.

6. Переславцев А. В., Слюняев А. А. Закономерности фракционирования малых элементов в никеленосных норит-диоритовых интрузиях Воронежского кристаллического массива // Геология рудных месторождений. 1991. №4. С.32-46. 7. Переславцев А. В., Слюняев А. А. Породообразующие минералы и петрогенезис никеленосных норит-диоритовых интрузий Воронежского кристаллического массива // Изв. АН СССР. Сер. геол. 1992. №11. С. 81-98.

8. Терентьев Р. А., Савко К. А. Высокомагнезиальные низкотитанистые габбро-гранитные серии в палеопротерозое 
восточной Сарматии: геохимия и условия формирования // Геология и геофизика. 2016. Т. 57. - № 6. С. 1155-1183.

9. Чернышов Н. М. Новый тип сульфндного никелевого оруденения Воронежского кристаллического массива // Геология рудных месторождений. 1985. № 3. С. 34-45.

10. Чернышов Н. М. Еланский тип сульфидных медно-никелевых месторождений и геолого-генетическая модель их формирования (Центральная Россия) // Геология рудных месторождений. 1995. Т. 37. №3. С. 220-236.

11. Черныпюв Н. М., Баянова Т. Б., Черныпова М. Н., Левкович Н. В. Возраст норит-диоритовых интрузий по изотопно-геохронологическим данным еланского никеленосного комплекса и их временные соотношения с габбро-норитами мамонского комплекса Воронежского кристаллического массива // Геология и геофизика. 1998. Т. 39(8). С. 1064-1071.

12. Chernyshov N. M., Pereslavtsev A. V. The Role of Accumulation in Forming the Nickeliferous Norite-Diorite Intrusions of the Voronezh Crystalline Massif// International Geology Review. 1994. V. 36. P. 587-604.

13. Terentiev R. A., Skryabin V. Yu., Santosh M. U-Pb zircon geochronology and geochemistry of Paleoproterozoic magmatic suite from East Sarmatian Orogen: tectonic implications on Co- lumbia supercontinent// Precambrian Research. 2016. V. 273. P. 165-184.

14. Терентьев Р. А. Петрогенезис синплутонических высокомагнезиальных порфировых даек из мафит-гранитоидных плутонов Восточно-Европейского кратона, Воронежский кристаллический массив // Геохимия. 2019. № 4. С. 356-371.

15. Петрографический кодекс России. Магматические, метаморфические, метасоматические, импактные образования. Издание второе. СПб.: Изд-во ВСЕГЕИ, 2008. 200 с.

16. Классификация магматических (изверженных) пород и словарь терминов. Рекомендации Подкомиссии по систематике изверженных пород Международного союза геологических наук: пер. с англ. М.: Недра, 1997. 248 с.

17. Петрографический словарь / Под ред. В.П. Петрова, О.А. Богатикова, Р.П. Петрова. М.: Недра, 1981.496 с.

18. Магматические горные породы. Т.1. М.: Наука, 1983. 368 c.

19. Streckeisen A. To each plutonic rock its proper name// Earth Sci. Rev., 1976. V. 12. P. 1-33

20. Terentiev R. A., Santosh M. High magnesian granitoids in the Precambrian continental crust: implication for the continuum between ferro-potassic and magnesio-potassic rock suites // Lithos. 2018. V. 314-315. P. 669-682.

UDC 552.32/.22/.23 (470.324)

ISSN 1609-0691

DOI: https://doi.org/10.17308/geology.2020.2/2859

Received: 27.02 .2020

Accepted: 01.06.2020

Published online: 30.06 .2020

\title{
The nickeliferous Elan complex of the Voronezh Crystalline Massif: composition and nomenclature of the rocks
}

\author{
(C)2020 R. A. Terentiev ${ }^{\boxplus}$ \\ Voronezh State University, 1 Universitetskaya pl., Voronezh 394018, Russian Federation
}

\begin{abstract}
Introduction: In the structure of the Precambrian foundation of the Voronezh Crystalline Massif, subvolcanic bodies were detected that were attributed to the Elan norite-diorite complex. Two large sulphidic nickel deposits, Elan and Elki, are associated with it. The discrepancy between the traditional names of the rocks of the complex and the existing classifications stimulated us to publish this paper.

Methodology: Detailed petrochemical and petrographic studies were carried out.

Results and discussion: The Elan and Elki petrotypical plutons are subdivided into cumulative, differentiated, and dyke series. The rocks are part of the medium and acid formations of the calc-alkaline series; with the exception of cumulates, which are in the boundary region between the medium and main groups. The differentiated series is common and consists of ultra-magnesium granitoids. It forms continuous rows of: (1) biotite-orthopyroxene meladiorite - quartz meladiorite - quartz melamonzodiorite - melagranodiorite and (2) hornblende-biotite, biotite, and quartz diorite - tonalite - granodiorite - monzogranite. The cumulates are represented by melanorite, plagioorthopyroxenite, quartz-containing melanorite, and quartz melagabbrodiorite, as well as hornblendite, hornblende melagabbro, and quartz melagabbrodiorite.
\end{abstract}

\footnotetext{
Roman A. Terentiev, e-mail: terentiev@geol.vsu.ru
} 
Conclusions: The conclusion was made about the need to review the composition of the complex (the proposed new name: melanorite - quartz meladiorite - granodiorite Elan complex). It has been proposed to use the determined varieties in geological exploration to carry out the petrographic control of sulphide mineralisation.

Keywords: Paleoproterozoic Era, sulphide ores, metalliferous rocks, classification of rocks, ultra-magnesium granitoids.

For citation: Terentiev R. A. The nickeliferous Elan complex of the Voronezh Crystalline Massif: composition and nomenclature of the rocks. Vestnik Voronezhskogo gosudarstvennogo universiteta. Seriya: Geologiya $=$ Proceedings of Voronezh State University. Series: Geology. 2020. No. 2. pp. 58-68. DOI: https://doi.org/10.17308/geology.2020.2/2859

Conflict of interests: The author declare the absence of obvious and potential conflicts of interest related to the publication of this article.

\section{REFERENCES}

1. Bocharov V. L., Frolov S. M., Chernyshov N. M. Structure and composition of the Elan nickeliferous pluton in the marginal portion of the Voronezh crystalline massif. Paper I. Geology and petrography: Izvestiya Vuzov, Geologiya i Razvedka. 1986, no. 4, pp. 10-19 (in Russ.).

2. Bocharov V. L., Frolov S. M., Chernyshov N. M. Structure and composition of the Elan nickeliferous pluton in the marginal portion of the Voronezh crystalline massif. Paper II. Petrochemistry: Izvestiya Vuzov, Geologiya i Razvedka. 1986, no. 5, pp. 4248 (in Russ.).

3. Bocharov V. L., Plaksenko A. N., Frolov S. M., Kasatov A. S. On the primary komatiite source of the nickel sulfide ores and norite-diorite intrusions of the VCM. Geokhimiya = Geokhimiya . 1987, no. 3, pp. 430-437 (in Russ.).

4. Bocharov V. L., Plaksenko A. N. Petrologic criteria for recognizing norite-diorite intrusions with regenerated nickel sulfide ores. International Geology Review. 1989, vol. 31(6), pp. 590594. DOI: $10.1080 / 00206818909465911$

5. Pereslavtsev A. V. Petrologiya norit-dioritovykh intruzii dokembriya Voronezhskogo kristallicheskogo massiva $v$ svyazi s problemoi ikh nikelevogo potentsiala. Dis. kand. geol.-min. nauk [Petrology of the norite-diorite intrusions of the Precambrian Voronezh crystalline massif in connection with the problem of their nickel potential. Ph.D. thesis], Voronezh Univ. Press, 1993. 197 p. (in Russ.).

6. Pereslavtsev A. V., Slyunyayev A. A. Trends of fractionation of minor elements in the nickeliferous norite-diorite intrusions of the Voronezh crystalline massif. Geologiya Rudnykh Mestorozhdeniy = Ore Deposits Geology. 1991, no. 4, pp. 32-46 (in Russ.). 7. Pereslavtsev A. V., Slyunyaev A. A. Rock-forming minerals and petrogenesis of the nickeliferous norite-diorite intrusions of the Voronezh crystalline massif. Izvestiya Akademii Nauk, Ser. geol.$=$ Proceedings of the Academy of Sciences, Ser. geol. 1992, no. 11, pp. 81-98 (in Russ.).

8. Terentiev R. A., Savko K. A. Paleoproterozoic high-Mg lowTi gabbro-granite series in eastern Sarmatia: geochemistry and formation conditions. Russian Geology and Geophysics. 2016, vol. 57, pp. 907-932.

9. Chernyshov N. M. A new type of sulfide nickel mineralization of the Voronezh crystalline massif. International Geology Review. 1985, vol. 27(7), pp. 859-869. DOI: 10.1080/00206818509466472
10. Chernyshov N. M. Elan-type of sulfide $\mathrm{Cu}-\mathrm{Ni}$ deposites and geological and genetic model its origine, Central Russia. Geologiya Rudnykh Mestorozhdeniy = Ore Deposits Geology. 1995, vol. 37(3), pp. 220-236 (in Russ.).

11. Chernyshov N. M., Bayanova T. B., Chernyshova M. N., Levkovich N. V. The U-Pb age of the norite-diorite intrusions of the nickel-bearing complex and their time correlations with the gabbronorites of the Mamonskii complex of the Voronezh crystalline massif. Geologiya i Geofizika = Geology and Geophysics. 1998, vol. 39(8), pp. 1064-071 (in Russ. with English abstract). 12. Chernyshov N. M., Pereslavtsev A. V. The Role of Accumulation in Forming the Nickeliferous Norite-Diorite Intrusions of the Voronezh Crystalline Massif. International Geology Review. 1994, vol. 36, pp. 587-604.

13. Terentiev R. A., Skryabin V. Yu., Santosh M. U-Pb zircon geochronology and geochemistry of Paleoproterozoic magmatic suite from East Sarmatian Orogen: tectonic implications on Columbia supercontinent. Precambrian Research. 2016, vol. 273, pp. $165-184$.

14. Terentiev R. A. Petrogenesis of synplutonic high-Mg porphyritic dikes from mafic-granitoid plutons of the Voronezh Crystalline Massif, East European Platform. Geochemistry International. 2019, vol. 57, no. 4, pp. 384-399.

15. Petrographic code of Russia. Magmatic, metamorphic, metasomatic, impact rock-assemblages. Second edition. Sankt Peterburg, VSEGEI Press. 2008. 200 p. (in Russ.)

16. Le Maitre, R.W. (ed.). Igneous Rocks. A Classification and Glossary of Terms. Recommendations of the International Union of Geological Sciences Subcommission on the Systematics of Igneous Rocks, 2nd ed. Cambridge, New York, Melbourne: Cambridge University Press. Geological Magazine. 2002. 140, 367 p. 17. Petrograficheskii slovar' [Petrographic dictionary]. V. P. Petrov, O.A. Bogatikov, R.P. Petrov eds. Moskow, Nedra Publ., 1981, 496 p. (in Russ.)

18. Magmaticheskie porody [Igneous rocks]. V.1. Moscow: Nauka Publ. 1983. 368 p. (in Russ.)

19. Streckeisen A. To each plutonic rock its proper name. Earth Sci. Rev. 1976, vol. 12, pp. 1-33.

20. Terentiev R. A., Santosh M. High magnesian granitoids in the Precambrian continental crust: implication for the continuum between ferro-potassic and magnesio-potassic rock suites. Lithos, 2018, vol. 314-315, pp. 669-682.
Терентьев Роман Анатольевич - к. г.-м. н., Воронежский государственный университет, Воронеж, Российская Федерация; E-mail: terentiev@geol.vsu.ru

ORCID https://orcid.org/0000-0001-9733-6085

Автор прочитал и одобрил окончательный вариант рукописи.
Roman A. Terentiev - PhD in Geol-Min., Voronezh State University, Voronezh, Russian Federation;

E-mail: terentiev@geol.vsu.ru

ORCID https://orcid.org/0000-0001-9733-6085

Author have read and approved the final manuscript. 